\title{
Synchronized high-resolution bed-level change and biophysical data from 10 marsh-mudflat sites in northwestern Europe
}

\author{
Zhan Hu ${ }^{1,2}$, Pim W. J. M. Willemsen ${ }^{3,4}$, Bas W. Borsje ${ }^{3}$, Chen Wang ${ }^{5}$, Heng Wang ${ }^{2,6}$, \\ Daphne van der Wal ${ }^{4,7}$, Zhenchang Zhu ${ }^{8}$, Bas Oteman ${ }^{4}$, Vincent Vuik ${ }^{9,10}$, Ben Evans ${ }^{11}$, Iris Möller ${ }^{12}$, \\ Jean-Philippe Belliard ${ }^{13}$, Alexander Van Braeckel ${ }^{14}$, Stijn Temmerman ${ }^{13}$, and Tjeerd J. Bouma ${ }^{4,15}$ \\ ${ }^{1}$ Guangdong Provincial Key Laboratory of Marine Resources and Coastal Engineering, \\ School of Marine Sciences, Sun Yat-sen University, Zhuhai, 519082, China \\ ${ }^{2}$ Southern Marine Science and Engineering Guangdong Laboratory, Zhuhai, 519080, China \\ ${ }^{3}$ Water Engineering and Management, Faculty of Engineering Technology, University of Twente, \\ P.O. Box 217, 7500 AE Enschede, the Netherlands \\ ${ }^{4}$ Department of Estuarine and Delta Systems, NIOZ Royal Netherlands Institute for Sea Research, Utrecht \\ University, P.O. Box 140, 4400 AC Yerseke, the Netherlands \\ ${ }^{5}$ Satellite Application Center for Ecology and Environment, Ministry of Ecology and Environment, State \\ Environmental Protection Key Laboratory of Satellite Remote Sensing, Beijing, 100094, China \\ ${ }^{6}$ School of Marine Engineering and Technology, Sun Yat-Sen University, Zhuhai, 519082, China \\ ${ }^{7}$ Faculty of Geo-Information Science and Earth Observation (ITC), University of Twente, \\ P.O. Box 217, 7500 AE Enschede, the Netherlands \\ ${ }^{8}$ Institute of Environmental and Ecological Engineering, Guangdong University of Technology, \\ Guangzhou, 510030, China \\ ${ }^{9}$ Faculty of Civil Engineering and Geosciences, Delft University of Technology, \\ P.O. Box 5048, 2600 GA Delft, the Netherlands \\ ${ }^{10}$ HKV Consultants, P.O. Box 2120, 8203 AC Lelystad, the Netherlands \\ ${ }^{11}$ Department of Geography, University of Cambridge, Cambridge, CB2 3EN, UK \\ ${ }^{12}$ Department of Geography, Trinity College Dublin, Dublin 2, D02 PN40, Ireland \\ ${ }^{13}$ Ecosystem Management Research Group, University of Antwerp, 2610 Antwerp, Belgium \\ ${ }^{14}$ Research Institute for Nature and Forest (INBO), Havenlaan 88, 1000 Brussels, Belgium \\ ${ }^{15}$ Department of Physical Geography, Utrecht University, P.O. Box 80.115, 3508 TC Utrecht, the Netherlands
}

Correspondence: Heng Wang (wangheng3@mail.sysu.edu.cn)

Received: 27 March 2020 - Discussion started: 4 June 2020

Revised: 6 December 2020 - Accepted: 8 December 2020 - Published: 12 February 2021

\begin{abstract}
Tidal flats provide valuable ecosystem services such as flood protection and carbon sequestration. Erosion and accretion processes govern the ecogeomorphic evolution of intertidal ecosystems (marshes and bare flats) and, hence, substantially affect their valuable ecosystem services. To understand the intertidal ecosystem development, high-frequency bed-level change data are thus needed. However, such datasets are scarce due to the lack of suitable methods that do not involve excessive labour and/or costly instruments. By applying newly developed surface elevation dynamics (SED) sensors, we obtained unique high-resolution daily bed-level change datasets in the period 2013-2017 from 10 marsh-mudflat sites situated in the Netherlands, Belgium, and the United Kingdom in contrasting physical and biological settings. At each site, multiple sensors were deployed for 9-20 months to ensure sufficient spatial and temporal coverage of highly variable bed-level change processes. The bed-level change data are provided with synchronized hydrodynamic data, i.e. water level, wave height, tidal current velocity, medium sediment grain size $\left(D_{50}\right)$, and chlorophyll $a$ level at four sites. This dataset has
\end{abstract}


revealed diverse spatial morphodynamics patterns over daily to seasonal scales, which are valuable to theoretical and model development. On the daily scale, this dataset is particularly instructive, as it includes a number of storm events, the response to which can be detected in the bed-level change observations. Such data are rare but useful to study tidal flat response to highly energetic conditions.

The dataset is available from 4TU.ResearchData (https://doi.org/10.4121/12693254.v4; Hu et al., 2020), which is expected to expand with additional SED sensor data from ongoing and planned surveys.

\section{Introduction}

Salt marshes and the adjacent tidal flats are co-evolving coastal ecosystems of global importance (Mcowen et al., 2017; Schuerch et al., 2018). They provide multiple ecosystem services such as carbon sequestration (Mcleod et al., 2011; Duarte et al., 2013), hosting migratory birds (Van Eerden et al., 2005), and protecting coastal communities and infrastructures by attenuating waves (Temmerman et al., 2013; Möller et al., 2014; Vuik et al., 2016). These systems are known as dynamic biogeomorphic systems (Knox, 1972; Friedrichs, 2011; Fagherazzi et al., 2012). Their bed form is continuously shaped by the interactions between physical and biological processes, including tidal currents, wind waves, and sediment delivery, as well as bioturbation and bioaggregation, which jointly determine the time evolution of these systems (Le Hir et al., 2000; Yang et al., 2008; Green and Coco, 2014; Dai et al., 2016, 2018; D'Alpaos et al., 2016). Evaluating the impact of changing sea level and increasing storminess on these valuable coastal ecosystems is of high socioeconomic importance (Mariotti and Fagherazzi, 2010; Temmerman and Kirwan, 2015; Schuerch et al., 2018). More research is clearly needed to reveal the key biogeomorphic processes that control the persistence of these intertidal ecosystems to enable an accurate assessment of their resilience.

Recent studies have shown that short-term (daily- to seasonal-scale) hydrodynamic forcing and the related bedlevel changes exert a critical control on the (i) recruitment of marsh seedlings (Balke et al., 2014; Silinski et al., 2016; Cao et al., 2018) and benthic invertebrates (Bouma et al., 2001; Nambu et al., 2012), (ii) initiation of marsh lateral erosion (Bouma et al., 2016), and (iii) position and dynamics of the existing marsh edge (Willemsen et al., 2018; Evans et al., 2019). Large spatial (e.g. dense vegetation vs. bare) and temporal (e.g. stormy vs. calm) variation in bed-level changes has been observed in intertidal systems (Spencer et al., 2016; $\mathrm{Hu}$ et al., 2017). Thus, to better understand intertidal bedlevel change and its impact on biogeomorphic evolution, bedlevel change data at a high resolution and with sufficient spatiotemporal coverage are needed. However, such data to support theory and model development are scarce. For instance, we are lacking the ability to model cyclic marsh expansionretreat dynamics, since the existing data are insufficient to derive tipping points that lead to the expansion-retreat phase shift. Existing measurements of intertidal bed-level dynamics typically have limited temporal (e.g. two to five tidal cycles) or spatial resolution (e.g. one to two stations) (Whitehouse and Mitchener, 1998; Shi et al., 2014; Zhu et al., 2014; Hunt et al., 2016), as high-resolution datasets require excessive labour or a high cost for instruments (Andersen et al., 2006).

In light of these limitations, surface elevation dynamics (SED) sensors have been developed to record daily bed-level dynamics with high accuracy while reducing the unit cost and labour during deployment (Hu et al., 2015). These sensors have been applied in the field at 10 sites in the Netherlands (Westerschelde and Wadden Sea), Belgium (Zeeschelde), and the United Kingdom (Thames and Humber estuaries) from a number of previous studies (Hu et al., 2017; Willemsen et al., 2018; Belliard et al., 2019). This paper presents a comprehensive collection of the existing SED sensor dataset. It is expected to provide an opportunity to assist future studies on intertidal biogeomorphic processes as it offers (i) high-temporal-resolution (daily) bed-level changes; (ii) long temporal coverage, i.e. 9-20 months depending on the site; (iii) large spatial coverage, i.e. multiple sensors deployed in both marshes and bare tidal flats across 10 sites; and (iv) synchronized biophysical measurements, i.e. hydrodynamic measurements (water level, flow velocity, and significant wave height), sediment properties (grain size, chlorophyll $a$ level, and organic matter content), and bathymetrictopographic profiles. In this paper, we present the full dataset from 10 sites and briefly discuss the potential research questions that can be addressed by exploring such datasets.

\section{Site description}

The dataset includes 10 observation sites from northwestern Europe: seven sites from the Netherlands, one site from Belgium, and two sites from the United Kingdom (Fig. 1). For all seven Dutch sites, sites 1-6 are in the Westerschelde estuary, and only site 7 is in the Wadden Sea region. Near Zuidgors in the Westerschelde, there are two sites (sites 1 and 2). At site 1 (Zuidgors A), only the bare tidal flat was monitored, whereas at site 2 (Zuidgors B), both the bare tidal flat and marsh area were included in the monitoring. The only Belgian site (site 8 at Galgeschoor) is located in the Zeeschelde estuary, which is the upstream part of the Westerschelde estuary. Site 8 has two observational transects: north and south transects with 
different bathymetries. The two British sites, site 9 (Tillingham) and 10 (Donna Nook), are on the southeastern coast of England (Fig. 1).

Overall, these 10 sites cover areas of differing tidal range, wave exposure, sediment grain size, and marsh vegetation species (Table 1). Notably, site 10 (Donna Nook) has the largest tidal range $(6.9 \mathrm{~m})$, whereas site 9 (Tillingham) has highest wave exposure. The observations were conducted in the period 2013-2017. The duration of the observation at each site varies from 9 to 20 months (Table 1). At all sites, bed-level changes were monitored daily with multiple SED sensors. For all sites except sites 1, 4, and 8, SED sensors were deployed on both bare flat and marsh areas. The coordinates of the monitoring stations as well as the bathymetry of the measuring transects were measured by real-time kinematic Global Positioning System (RTK-GPS) instruments with an accuracy of $15 \mathrm{~mm}$ in the vertical and $10 \mathrm{~mm}$ in the horizontal. Besides the daily bed-level observation, biophysical measurements were available at some sites, i.e. water level, wave height, current velocity, surface sediment grain size, and chlorophyll $a$ level as well as organic matter content.

\section{Method}

\subsection{Bed-level change observation}

The bed-level dynamics at each site were monitored using recently developed SED sensors (Hu et al., 2015; see Fig. 2). These sensors are stand-alone instruments with all parts for measuring and data logging and include batteries enclosed in a transparent tube. The measuring part is an array of lightsensitive cells that measure light intensity. When in use, a sensor is inserted vertically into the bed, leaving about half of the measuring array above the bed. The cells above and below the bed receive different amount of the daylight, which will lead to different voltage outputs in the array of cells. By using an autonomous script, the noise in the raw signal is reduced, and the bed level is determined as where the large transition from high to low voltage occurred (Fig. 2d; see Willemsen et al., 2018). When bed accretion or erosion occur, the transition point moves up or down in the measuring array. Thus, by recording the changes of the transition point, we can measure the bed-level changes. In some cases, scouring holes occurred around some of the deployed SED sensors, with the maximum depth of $5 \mathrm{~cm}$. They typically result in two transition points in the array, corresponding to the bottom and the top of the scouring holes. In such cases, the bed level was determined as the vertical position at the top of the scouring holes. Details of SED sensor data processing are included in Willemsen et al. (2018). We note that the SED technique does not include effects of deep subsoil subsidence on bed-level changes. For a typical deployment period of the SED sensors (10-15 months), subsidence in the study areas is mainly related to glacial isostatic adjustment after the last ice age, with values in the order of less than 1 or a few millimetres over the considered time periods (Vink et al., 2007), and therefore these values are mostly much less than those of vertical bed-level changes recorded by the SED sensors.

As the sensor is dependent on the presence of daylight, the measuring window is daytime during low tide. Data acquired while the sensors were submerged or during night were excluded from the analysis. For most of the time, SED sensors provided at least one measurement every day, i.e. daily temporal resolution. To avoid recording bed-level data when sensors were submerged, an effective measuring window was set as $2 \mathrm{~h}$ around low tide. The tidal fluctuation of water level was recorded by pressure sensors deployed close to SED sensors. In such a window, we used the averaged readings as a bed-level observation point.

The accuracy of the sensors has been compared to a precise manual method (i.e. sedimentation-erosion bar) (Hu et al., 2015). The manual measurements were conducted weekly from 13 June to 17 July 2014 at the second most seaward measuring station of site 1 (Zuidgors A). These observations serve as an independent quality control of our automatic SED sensor measurements. Good agreement $\left(R^{2}=\right.$ 0.89 ) has been obtained between these two methods (detailed in Hu et al., 2015). The estimated operational accuracy of the SED sensors is $5.0 \mathrm{~mm}$ with a $3.9 \mathrm{~mm}$ standard deviation. Additionally, good agreement between the SED sensors and sedimentation-erosion bar measurements has been obtained at site 8 (Galgeschoor) over an 18-month parallel measurement (Belliard et al., 2019).

\subsection{Hydrodynamics measurements}

Bed-level changes in the intertidal environment are closely related to the local hydrodynamic forcing. We measured hydrodynamic parameters of water level, wave height, and tidal current velocity simultaneously with the bed-level measurement at some of our observation sites (Table 1). To measure the water level and wave height, we deployed pressure sensors $0.05-0.10 \mathrm{~m}$ above the bed in the vicinity of the SED sensors at some of the sites (see Table 1). At sites 1, 3, 4, and 6, OSSI-010-003C pressure sensors (Ocean Sensor Systems, Inc.) were used to measure pressure at a frequency of $5 \mathrm{~Hz}$ over a period of $7 \mathrm{~min}$, with a $15 \mathrm{~min}$ interval. The mean water level is determined by the mean pressure in an interval. The significant wave height $\left(H_{\mathrm{S}}\right)$ and peak wave period $\left(T_{\mathrm{p}}\right)$ were derived from the dynamic wave pressure signals. The attenuation of pressure signals with water depth was corrected using the standard calculation methods as described in Tucker and Pitt (2001). The attenuation correction was only applied over the frequency range $0.05-0.4 \mathrm{~Hz}$, and the maximum correction factor was set as 5 to avoid overamplification of high-frequency signals (i.e. noise). A detailed description and the source of the data-processing routines can be found at http://neumeier.perso.ch/matlab/waves. html (last access: 28 January 2021). At sites 2, 5, 9, and 10, 


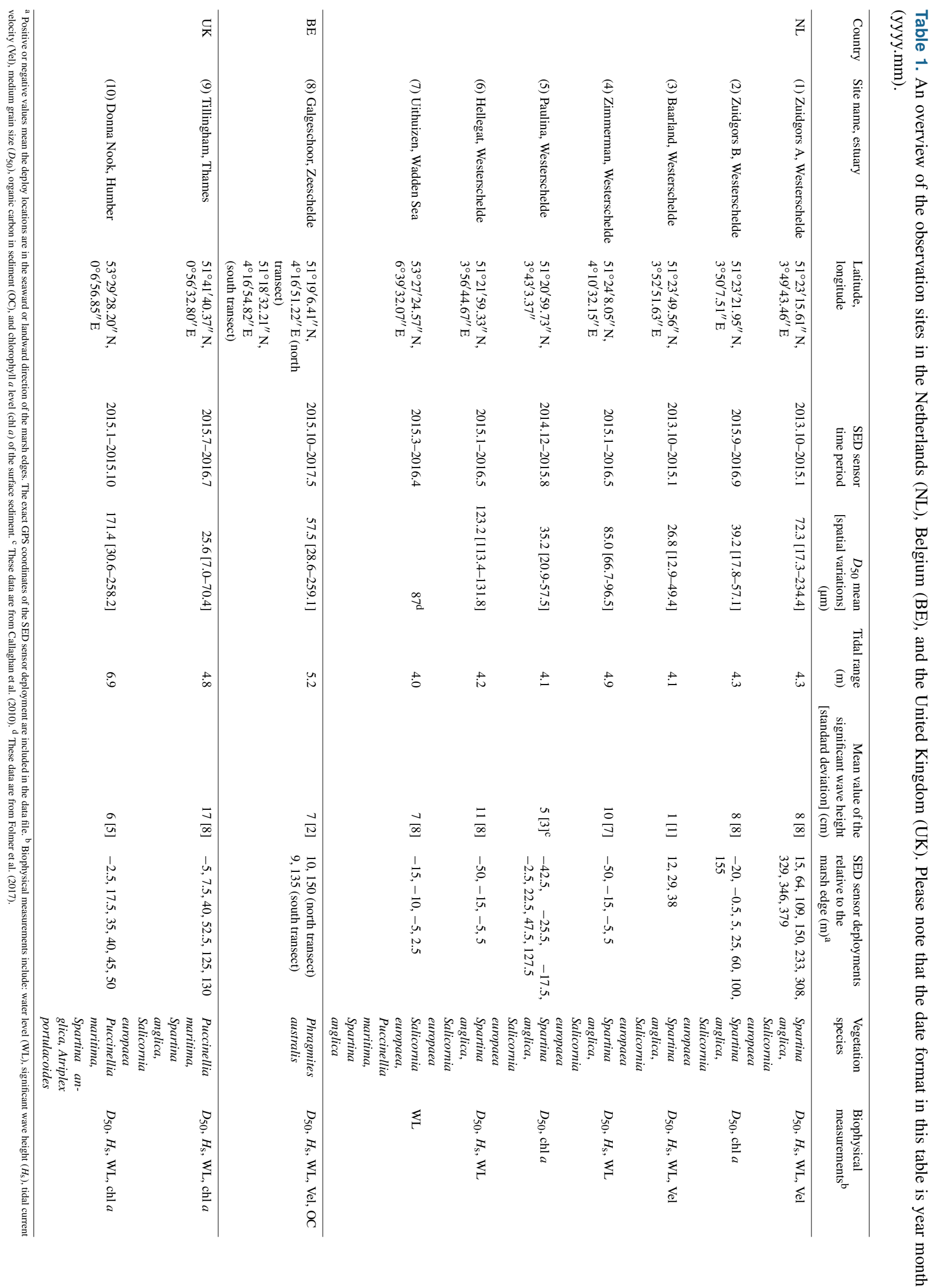




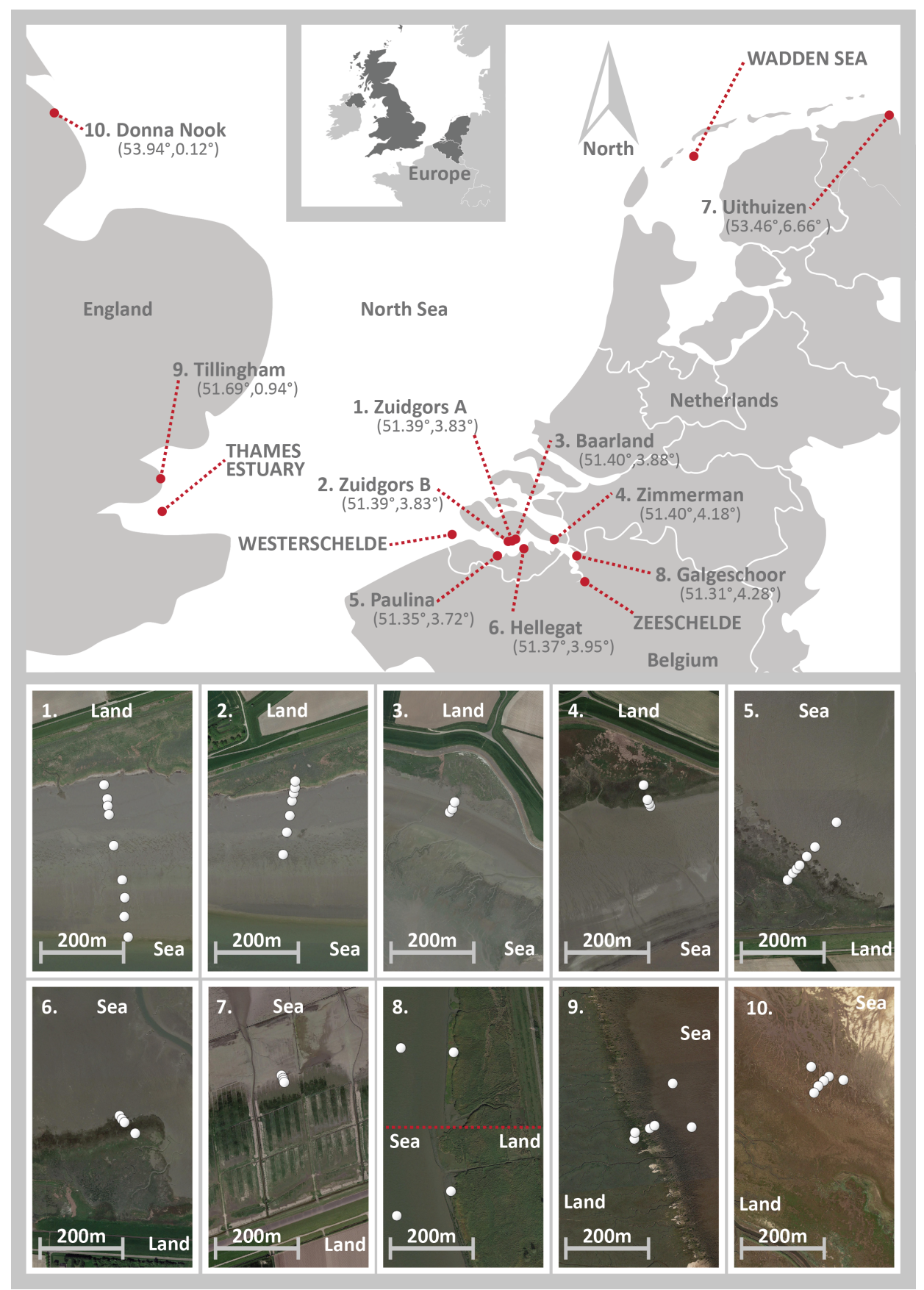

Figure 1. Locations and an overview of the observation sites in the Westerschelde and Wadden Sea in the Netherlands, Zeeschelde in Belgium, and the Thames and Humber estuaries in the United Kingdom. The lower 10 panels are the deployments of the SED sensor stations (white dots) at the observation sites. The GPS coordinates of all SED sensor stations are included in the data file. In panel 8, the maps of the north and south measuring transects at site 8 (Galgeschoor) are bordered by a red dot line. Source of aerial images: (C) Google Earth.

pressure sensors (series PDCR 1830, Druck Ltd.) were used. Pressure was recorded at $4 \mathrm{~Hz}$ for 4096 readings $(\sim 17 \mathrm{~min})$ around high-tide slack water, as determined by an onboard algorithm on the data logger (Möller et al., 1999). This typically results in one set of wave parameters per tide. For site 8 , both OSSI-010-003C and PDCR 1830 pressure sensors were used. The measuring frequency was $16 \mathrm{~Hz}$ for the PDCR sensors and $20 \mathrm{~Hz}$ for the OSSI-010-003C sensors. More details on the sensor deployments at site 8 are included in Belliard et al. (2019).

At sites without pressure sensor measurements, the waterlevel data were obtained by nearby tidal gauge stations op- 
(a)

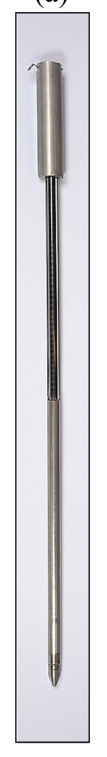

(b)

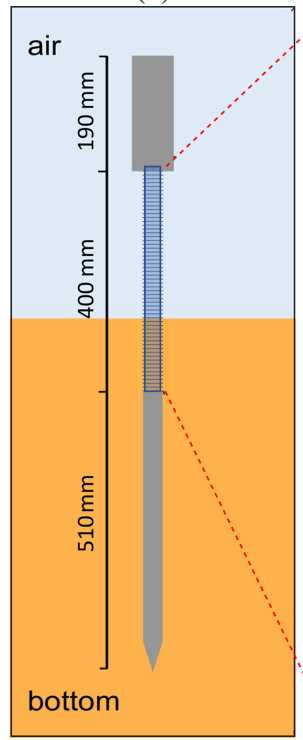

(c)

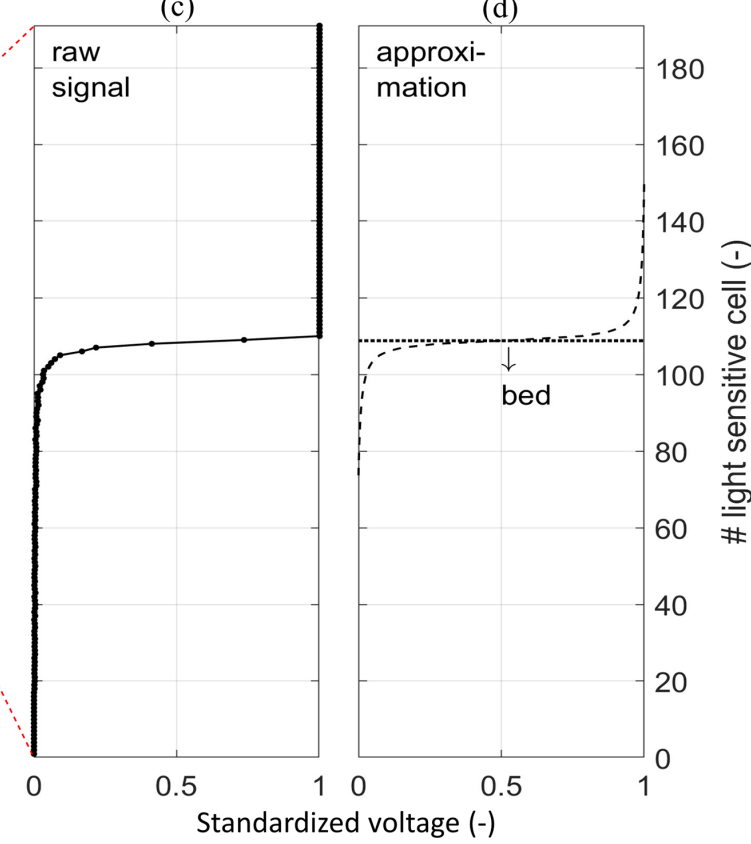

Figure 2. A photo (a) and schematization (b) of an SED sensor in operation. The sensor uses an array of light-sensitive cells to determine the position of the bed level, resulting in a transection in the raw voltage output of the array (c). The noise in the raw signal is reduced, and the bed level is obtained by approximating the signal by an autonomous script (d). Details of SED sensor data processing are included in Willemsen et al. (2018).

erated by Rijkswaterstaat (the Directorate-General for Public Works and Water Management, the Netherlands) or the British Oceanographic Data Centre (BODC). These data were obtained from Terneuzen (for site 2 at Zuidgors B and site 5 at Paulina) and Eemshaven (for site 7 at Uithuizen) with $10 \mathrm{~min}$ interval. For site 9 (Tillingham) and site 10 (Donna Nook), water-level data were obtained at the stations at Sheerness and Immingham with a 15 min interval. Tidal current velocity was measured by acoustic Doppler current profilers (ADCPs, Nortek Aquadopp) with a 5 or $10 \mathrm{~min}$ interval at sites 1, 3, and 8. Additionally, near-bed 3D current velocities were measured at site 8 using two acoustic Doppler velocimeters (ADVs, Nortek Vector). All hydrodynamic data are included in the current dataset.

\subsection{Sediment grain size and chlorophyll a monitoring}

To determine the median bed sediment grain size $\left(D_{50}\right)$, surface sediment samples (upper $2-3 \mathrm{~cm}$ ) were collected at most of the sites (see Table 1). $D_{50}$ of these samples was measured by a Malvern laser particle sizer. The chlorophyll $a$ level in the sediment is an indicator for diatom biomass. Diatoms act as bio-stabilizers on tidal flats by producing extracellular polymeric substances (EPSs) and as such can affect sediment bed-level dynamics (Underwood and Paterson 1993; Austen et al., 1999; Andersen et al., 2005). At sites 2, 5, 9, and 10, chlorophyll $a$ samples were collected from the upper $1 \mathrm{~cm}$ of the sediment using a small cut-off syringe. The process- ing procedures that were used to determine chlorophyll $a$ are described in Willemsen et al. (2018). Additionally, at site 8, organic matter content was determined for the upper $2 \mathrm{~cm}$ of surface sediment samples by loss on ignition.

\section{Data description}

\subsection{Daily bed-level changes with storm events}

At our study sites, daily bed-level observations were conducted for 9-20 months, which includes conditions with various hydrodynamic forcing. As an example, we show the daily bed-level change and the accompanying wave height at site 4 (Zimmerman) and site 6 (Hellegat) from February 2015 to May 2016 (Fig. 3). Waves in front $(5 \mathrm{~m})$ of the marsh cliffs at site 4 (Zimmerman) were generally smaller than at site 6 (Hellegat) (Fig. 3b vs. 3d). Additionally, at both sites, there was a strong reduction in wave height from the bare tidal flats into the marshes (Fig. 3a vs. $3 \mathrm{~b}$ and $3 \mathrm{c}$ vs. 3d). We observed that the bed-level fluctuation was more apparent on the bare tidal flats than in the marshes. Over the whole observation period, the bed-level fluctuation on the bare tidal flat was in the order of $5 \mathrm{~cm}$ at both sites, whereas bed level in the marshes stayed stable (station 1 of site 6 ) or experienced mild accretion (station 1 of site 4).

Notably, a number of storm events with high incident waves were captured during our measurements. During the two storm events in November 2015, $H_{\mathrm{s}}$ (significant wave 

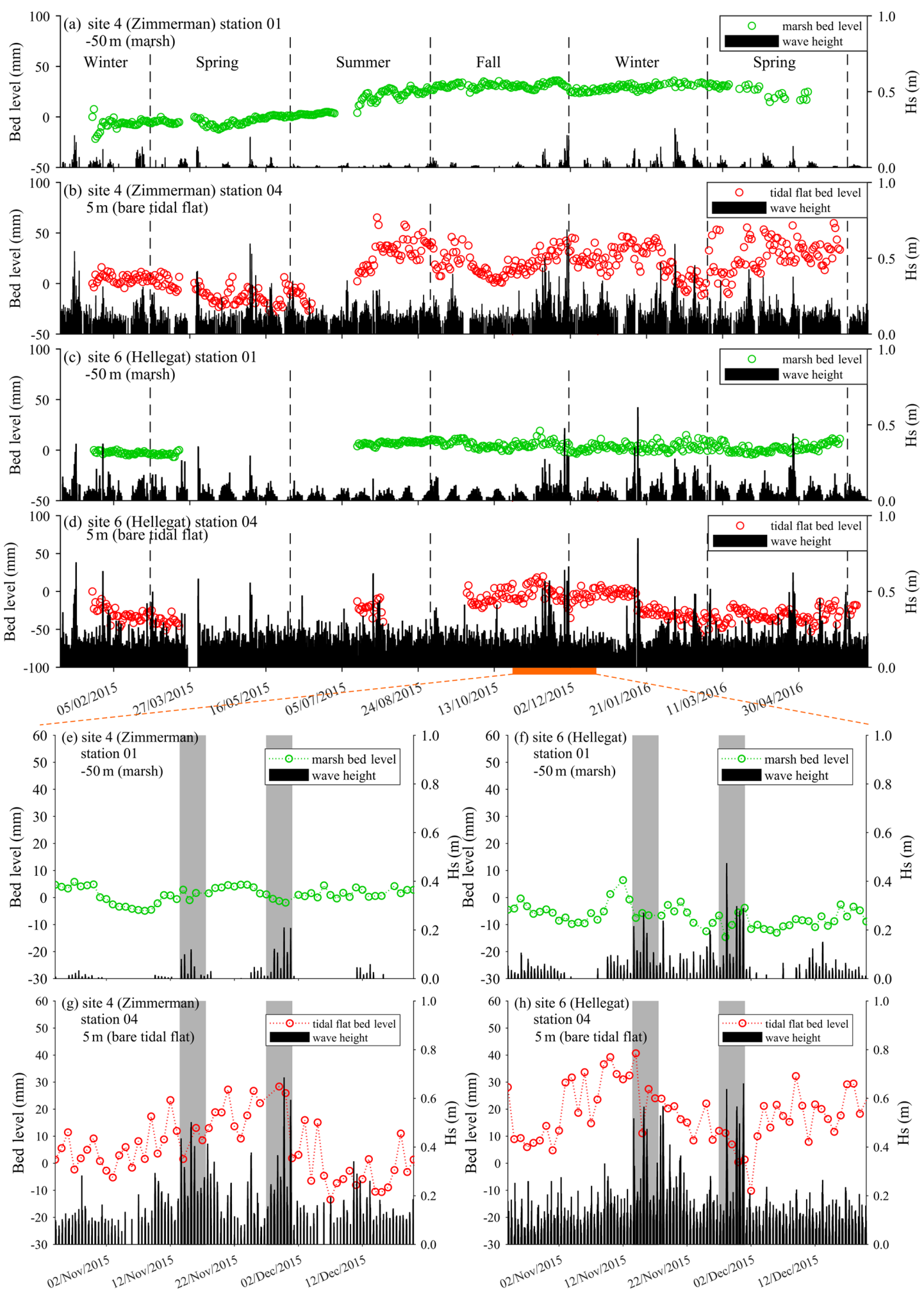

Figure 3. Time series of the bed-level change and significant wave height $\left(H_{\mathrm{s}}\right)$ at site 4 (Zimmerman; a, b, e, g) and site 6 (Hellegat; c, $\mathbf{d}, \mathbf{f}, \mathbf{h})$. The top four planes (a-d) are the entire dataset of four measuring stations from these two sites. Those of station 4 are on a bare tidal flat $(5 \mathrm{~m}$ seaward of the marsh edge), whereas those of station 1 are in the marsh $(50 \mathrm{~m}$ landward of the marsh edge). The gaps in the bed-level time series were due to temporary sensor failures. The lower four planes are the enlarged plots of the stormy period in NovemberDecember 2015. The dark grey shaded areas indicate bed-level changes during two storm events (13-17 November and 27 November-1 December 2015). 

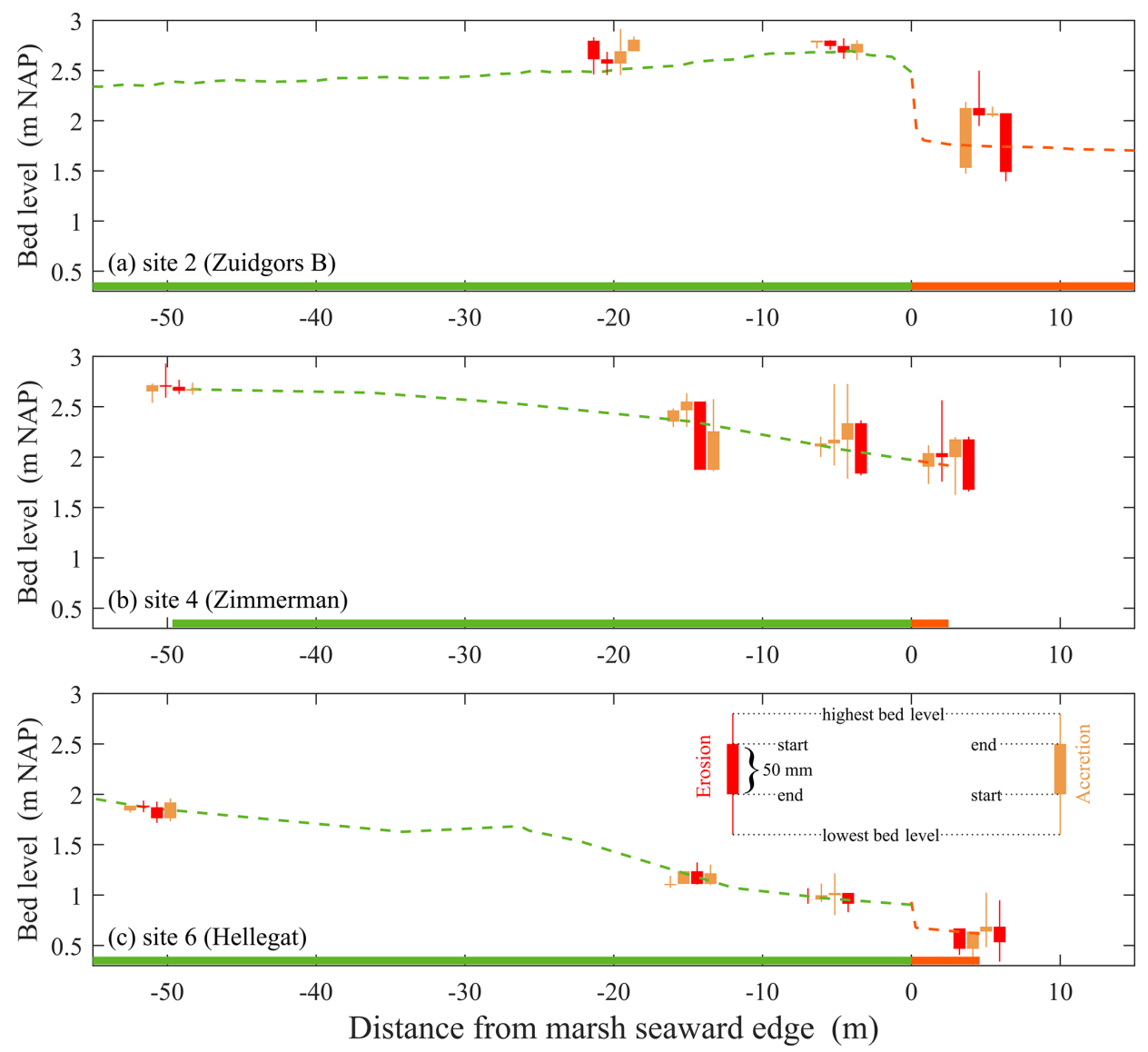

Figure 4. Seasonal bed-level changes at (a) site 2 (Zuidgors B), (b) site 4 (Zimmerman), and (c) site 6 (Hellegat) with bathymetry data (dashed green line). At each SED sensor station, the four bars from left to right indicate bed-level changes in spring (March-May), summer (June-August), autumn (September-November), and winter (December-February). The red bars indicate net erosion, and the yellow bars indicate net accretion. The observed highest and lowest bed levels in a season are indicated by the top and bottom of the bars.

height) exceeded $0.6 \mathrm{~m}$ on the bare flat stations at both site 4 and site 6 (Fig. $3 \mathrm{~g}$ and $\mathrm{h}$ ), whereas the mean $H_{\mathrm{s}}$ at the most seaward pressure sensors over the whole observation period was 0.104 and $0.113 \mathrm{~m}$ at these two stations, respectively. During the two storm events, sudden erosion of $2-3 \mathrm{~cm}$ occurred on the two bare flat stations. However, bed-level changes at the two marsh stations remained small (0.025 and $0.05 \mathrm{~m}$ at sites 4 and 6 , respectively). Across the 10 sites, the most severe short-term erosion was observed at site 1 (Zuidgors A) on 27 and 28 October 2013 during the St. Jude storm (Hu et al., 2015). In that event, severe bed erosion of $10.5 \mathrm{~cm}$ depth was captured by our SED sensor on one of the bare flat stations at site 1 (data not shown).

\subsection{Seasonal bed-level changes and biophysical changes}

Our observations at most sites were longer than 12 months. Thus, seasonal bed-level changes were captured in our dataset. Examples of seasonal bed-level changes at site 2 (Zuidgors B), site 4 (Zimmerman), and site 6 (Hellegat) show complex spatiotemporal variations (Fig. 4). Our data show that all stations at these three sites have alternating erosion and accretion seasons. There is no consistent seasonal erosion-accretion pattern for all stations. Winter is a typical season of bed erosion for stations on the bare flat but not for the stations in marshes.

Spatially, bed-level variations were generally smaller at the landward stations in the marshes and increased towards the seaward stations at all three sites. We further observed that the most seaward station at site 4 (Zimmerman) experienced net erosion over an annual timescale, whereas stations at the other two sites were in equilibrium; i.e. the degree of erosion was comparable to accretion. Profile elevation data show that marsh cliffs were distinct at site 2 (Zuidgors B) and site 6 (Hellegat), with the cliff height being 0.88 and $0.35 \mathrm{~m}$, respectively, whereas a cliff was absent at site 4 (Zimmerman) (Fig. 4). Notably, the magnitude of bed-level changes reduced from bare flat stations to the stations on the marsh plateaus at sites with marsh cliffs (sites 2 and 6), whereas there was no clear difference between the bare flat station 


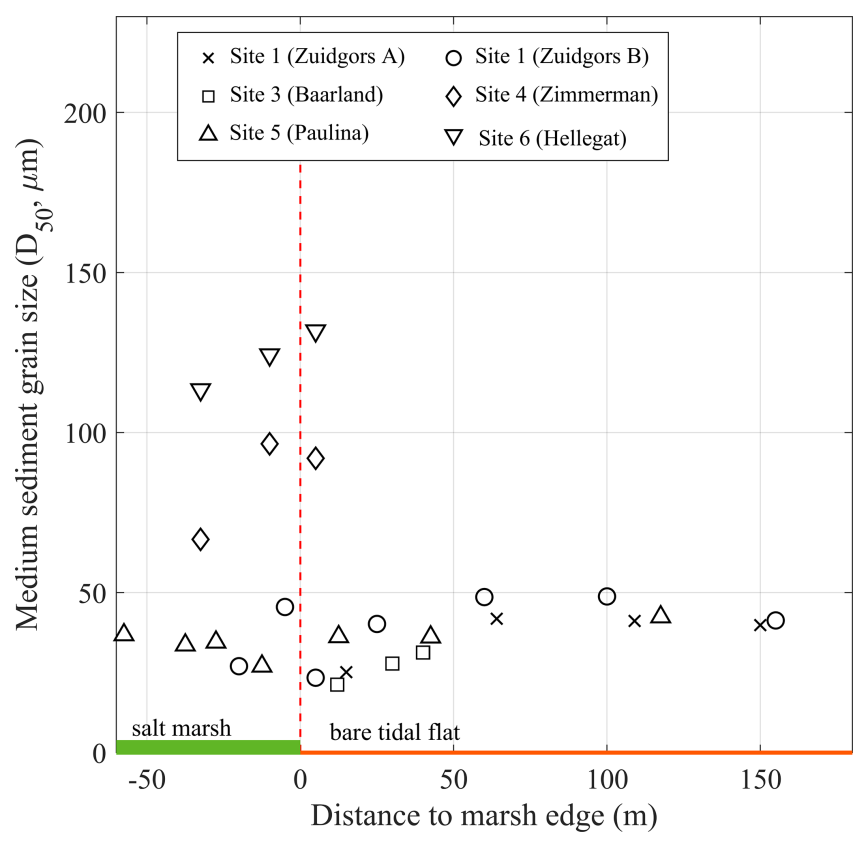

Figure 5. Median grain size of surface sediment $\left(D_{50}\right)$ measured along cross-shore transects of six study sites in the Westerschelde estuary.

and the neighbouring marsh station at the site without cliffs (site 4).

\subsection{Surface sediment characteristics}

Out of six sites with surface sediment grain size measurements, two sites (sites 4 and 6) in the Westerschelde had the largest median sediment grain size (Fig. 5). At these two sites, $D_{50}$ of the surface sediment was in the range of 66.7$131.8 \mu \mathrm{m}$, which was significantly coarser than the rest of the shown sites $(p=0<0.05)$. Within each site, there was no apparent difference in $D_{50}$ between the marsh and bare flat stations around the marsh edge $(50 \mathrm{~m}$ seaward and landward to the marsh edge). However, there was a gentle trend of coarsening from the landward to the seaward stations on bare flats.

Chlorophyll $a$ levels in surface sediment, a proxy for the diatom biomass and their bio-stabilization effect, were also obtained at some of our observation sites (Table 1). The chlorophyll $a$ levels at site 2 (Zuidgors B) showed great temporal variability (Fig. 6). For all stations, the chlorophyll $a$ levels were generally low in winter (January) but reached their maximum at the end of the spring (May). However, there was no clear spatial pattern in the chlorophyll $a$ levels across different stations, as the marsh stations had similar levels compared to the bare flat stations.

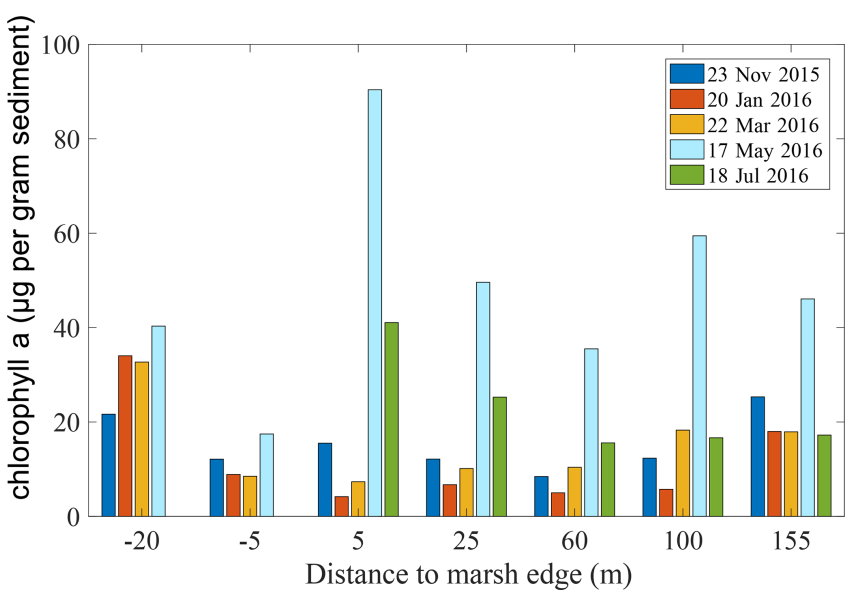

Figure 6. Spatiotemporal variation of the chlorophyll $a$ level in surface sediment (top $1 \mathrm{~cm}$ ) at site 2 (Zuidgors B).

\section{Data availability}

All data presented in this paper are available from 4TU.ResearchData (see $\mathrm{Hu}$ et al., 2020; https://doi.org/10.4121/12693254.v4). The repository includes data as well as instructions in readme files. Additionally, we expect that the current repository will expand with additional SED sensor data from ongoing as well as planned future observation programmes including mangrove wetlands, e.g. ANCODE project (Applying nature-based coastal defence to the world's largest urban area - from science to practice; https://www.noc.ac.uk/projects/ancode, last access: 29 January 2021).

\section{Conclusions}

By applying the novel high-resolution SED sensors, we were able to perform long-term (e.g. a few months to a few years) monitoring of the bed elevation changes at daily frequency. Our observations have been carried out at 10 sites in three countries in western Europe for a long duration (920 months). To our knowledge, the current dataset is the most complete and comprehensive to date on high-resolution (daily) intertidal bed-level changes.

The SED sensor data have been proven to be useful in revealing the relations between hydrodynamic forcing and intertidal bed-level dynamics (Hu et al., 2018; Belliard et al., 2019) and understanding the spatial variations in bedlevel dynamics from tidal flats to salt marshes (Wang et al., 2017; Willemsen et al., 2018; Baptist et al., 2019). The presented dataset may be of further use to the scientific community for addressing several research questions: in particular, our dataset can be used to provide insights into storm impacts on intertidal morphology and post-storm recovery (Leonardi et al., 2018), as the dataset pinpoints a number of storm events with precise pre- and post-storm bed-level ob- 
servations, which are otherwise difficult to measure by discontinuous manual methods. Furthermore, our dataset can be used to better understand biogeomorphic interactions in intertidal environments, which are important for marsh persistence, e.g. the control of short-term bed-level changes on marsh seedling establishment (Bouma et al., 2016; Cao et al., 2018), and the influence of marsh vegetation on sediment deposition (Yang et al., 2008; Schwarz et al., 2015; D'Alpaos and Marani, 2016). Lastly, our dataset may support morphodynamic-model developments. Due to the lack of relevant data, existing intertidal morphological models rarely deal with daily morphological changes. The presented dataset contains high-resolution data across 10 sites with various spatially (marsh vs. bare flat) and temporally (calm vs. stormy) varying conditions, which is valuable for model development and evaluation. In addition to process-based morphodynamic models (e.g. Delft3D; Lesser et al., 2004), this dataset can be of special interest to data-driven models based on machine learning techniques. Recent developments of the latter have shown great potential in resolving complex coastal morphodynamics (see a recent review in Goldstein et al., 2019). Therefore, the present dataset is expected to advance our understanding and prediction of tidal flat evolution and resilience.

Author contributions. ZH, DV, and TB developed the SED sensor. ZH, PWJMW, BWB, DvdV, ZZ, BO, VV, BE, IM, JPB, AVB, ST, and TJB collected the raw data. PWJMW and HW processed the data and graphs. $\mathrm{ZH}, \mathrm{CW}$, and $\mathrm{HW}$ prepared the paper with contributions from all authors.

Competing interests. The authors declare that they have no conflicts of interest.

Acknowledgements. The authors gratefully acknowledge financial support of a joint research project of the National Natural Science Foundation of China (no. 51761135022), NWO (no. ALWSD.2016.026), and EPSRC (no. EP/R024537/1; Sustainable Deltas) and a project from the Guangdong Provincial Department of Science and Technology (no. 2019ZT08G090). The dataset of Zuidgors A and Baarland was obtained as a part of the STW NWO project (grant no. 07324). The dataset of Hellegat and Zimmerman were obtained as part of the NWO-funded project BE-SAFE (grant no. 850.13.011). The dataset of Zuidgors B, Paulina, Tillingham, and Donna Nook was obtained as part of the EU FP7funded project FAST (Foreshore Assessment using Space Technology, grant no. 607131). Ben Evans and Iris Möller received support from the UK NERC RESIST project (grant no. NE/R01082X/1) for input into the paper preparation and writing process. The dataset of Galgeschoor was obtained in a project funded by Antwerp Port Authority.
Financial support. This research has been supported by a joint research project of the National Natural Science Foundation of China (no. 51761135022), NWO (no. ALWSD.2016.026), and EPSRC (no. EP/R024537/1; Sustainable Deltas) and a project from the Guangdong Provincial Department of Science and Technology (no. 2019ZT08G090). Ben Evans and Iris Möller received support from the UK NERC RESIST project (grant no. NE/R01082X/1) for input into the paper preparation and writing process.

Review statement. This paper was edited by François Schmitt and reviewed by Edward Anthony and Alvise Finotello.

\section{References}

Andersen, T. J., Lund-Hansen, L. C., Pejrup, M., Jensen, K. T., and Mouritsen, K. N.: Biologically induced differences in erodibility and aggregation of subtidal and intertidal sediments: a possible cause for seasonal changes in sediment deposition, J. Marine Syst., 55, 123-138, https://doi.org/10.1016/j.jmarsys.2004.09.004, 2005.

Andersen, T. J., Pejrup, M., and Nielsen, A. A.: Long-term and high-resolution measurements of bed level changes in a temperate, microtidal coastal lagoon, Mar. Geol., 226, 115-125, https://doi.org/10.1016/j.margeo.2005.09.016, 2006.

Austen, I., Andersen, T. J., and Edelvang, K.: The Influence of Benthic Diatoms and Invertebrates on the Erodibility of an Intertidal Mudflat, the Danish Wadden Sea, Estuar. Coast. Shelf S., 49, 99111, https://doi.org/10.1006/ecss.1998.0491, 1999.

Balke, T., Herman, P. M. J., and Bouma, T. J.: Critical transitions in disturbance-driven ecosystems: Identifying windows of opportunity for recovery, J. Ecol., 102, 700-708, https://doi.org/10.1111/1365-2745.12241, 2014.

Baptist, M. J., Gerkema, T., van Prooijen, B. C., van Maren, D. S., van Regteren, M., Schulz, K., Colosimo, I., Vroom, J., van Kessel, T., Grasmeijer, B., Willemsen, P., Elschot, K., de Groot, A. V., Cleveringa, J., van Eekelen, E. M. M., Schuurman, F., de Lange, H. J., and van Puijenbroek, M. E. B.: Beneficial use of dredged sediment to enhance salt marsh development by applying a "Mud Motor," Ecol. Eng., 127, 312-323, https://doi.org/10.1016/j.ecoleng.2018.11.019, 2019.

Belliard, J.-P., Silinski, A., Meire, D., Kolokythas, G., Levy, Y., Van Braeckel, A., Bouma, T. J., and Temmerman, S.: Highresolution bed level changes in relation to tidal and wave forcing on a narrow fringing macrotidal flat: Bridging intra-tidal, daily and seasonal sediment dynamics, Mar. Geol., 412, 123138, https://doi.org/10.1016/j.margeo.2019.03.001, 2019.

Bouma, H., Duiker, J. M. C., De Vries, P. P., Herman, P. M. J., and Wolff, W. J.: Spatial pattern of early recruitment of Macoma balthica (L.) and Cerastoderma edule (L.) in relation to sediment dynamics on a highly dynamic intertidal sandflat, J. Sea Res., 45, 79-93, https://doi.org/10.1016/S1385-1101(01)00054-5, 2001.

Bouma, T. J., van Belzen, J., Balke, T., van Dalen, J., Klaassen, P., Hartog, A. M., Callaghan, D. P., Hu, Z., Stive, M. J. F., Temmerman, S., and Herman, P. M. J.: Short-term mudflat dynamics drive long-term cyclic salt marsh dynamics, Limnol. Oceanogr., 61, 2261-2275, https://doi.org/10.1002/lno.10374, 2016. 
Callaghan, D. P., Bouma, T. J., Klaassen, P., van der Wal, D., Stive, M. J. F., and Herman, P. M. J.: Hydrodynamic forcing on saltmarsh development: Distinguishing the relative importance of waves and tidal flows, Estuar. Coast. Shelf Sci., 89, 73-88, 2010.

Cao, H., Zhu, Z., Balke, T., Zhang, L., and Bouma, T. J.: Effects of sediment disturbance regimes on Spartina seedling establishment: Implications for salt marsh creation and restoration, Limnol. Oceanogr., 63, 647-659, https://doi.org/10.1002/lno.10657, 2018.

Dai, Z., Fagherazzi, S., Mei, X., and Gao, J.: Decline in suspended sediment concentration delivered by the Changjiang (Yangtze) River into the East China Sea between 1956 and 2013, Geomorphology, 268, 123-132, https://doi.org/10.1016/j.geomorph.2016.06.009, 2016.

Dai, Z., Mei, X., Darby, S. E., Lou, Y., and Li, W.: Fluvial sediment transfer in the Changjiang (Yangtze) riverestuary depositional system, J. Hydrol., 566, 719-734, https://doi.org/10.1016/j.jhydrol.2018.09.019, 2018.

D'Alpaos, A. and Marani, M.: Reading the signatures of biologic-geomorphic feedbacks in saltmarsh landscapes, Adv. Water Resour., 93, 265-275, https://doi.org/10.1016/j.advwatres.2015.09.004, 2016.

D'Alpaos, A., Toffolon, M., and Camporeale, C.: Ecogeomorphological feedbacks of water fluxes, sediment transport and vegetation dynamics in rivers and estuaries, Adv. Water Resour., 93, 151-155, https://doi.org/10.1016/j.advwatres.2016.05.019, 2016.

Duarte, C., Losada, I. J., Hendriks, I., Mazarrasa, I., and Marba, N.: The role of coastal plant communities for climate change mitigation and adaptation, Nat. Clim. Change, 3, 961-968, https://doi.org/10.1038/nclimate1970, 2013.

Evans, B. R., Möller, I., Spencer, T., and Smith, G.: Dynamics of salt marsh margins are related to their three-dimensional functional form, Earth Surf. Process. Landf., 44, 1816-1827, https://doi.org/10.1002/esp.4614, 2019.

Fagherazzi, S., Kirwan, M. L., Mudd, S. M., Guntenspergen, G. R., Temmerman, S., D’Alpaos, A., Van De Koppel, J., Rybczyk, J. M., Reyes, E., Craft, C., and Clough, J.: Numerical models of salt marsh evolution: Ecological, geomorphic, and climatic factors, Rev. Geophys., 50, 2011RG000359, https://doi.org/10.1029/2011RG000359, 2012.

Folmer, E., Dekinga, A., Holthuijsen, S., Van der Meer, J., Mosk, D., Piersma, T., and van der Veer, H.: Species Distribution Models of Intertidal Benthos: Tools for Assessing the Impact of Physical and Morphological Drivers on Benthos and Birds in the Wadden Sea, NIOZ, Texel, The Netherlands, available at: http: //www.vliz.be/imisdocs/publications/77/307577.pdf (last access: 29 January 2021), 2017.

Friedrichs, C. T.: Tidal Flat Morphodynamics: A Synthesis, in Treatise on Estuarine and Coastal Science, edited by Wolanski, E. and McLusky, D., Academic Press, Waltham, https://doi.org/10.1016/B978-0-12-374711-2.00307-7, 137-170, 2011.

Goldstein, E. B., Coco, G., and Plant, N. G.: A review of machine learning applications to coastal sediment transport and morphodynamics, Earth-Sci. Rev., 194, 97-108, https://doi.org/10.1016/j.earscirev.2019.04.022, 2019.
Green, M. O. and Coco, G.: Review of wave-driven sediment resuspension and transport in estuaries, Rev. Geophys., 52, 77-117, https://doi.org/10.1002/2013RG000437, 2014.

$\mathrm{Hu}$, Z., Lenting, W., van der Wal, D., and Bouma, T. J.: Continuous monitoring bed-level dynamics on an intertidal flat: Introducing novel, stand-alone highresolution SED-sensors, Geomorphology, 245, 223-230, https://doi.org/10.1016/j.geomorph.2015.05.027, 2015.

Hu, Z., van der Wal, D., Cai, H., van Belzen, J., and Bouma, T. J.: Dynamic equilibrium behaviour observed on two contrasting tidal flats from daily monitoring of bed-level changes, Geomorphology, 311, 114-126, https://doi.org/10.1016/j.geomorph.2018.03.025, 2018.

Hu, Z., Willemsen, P. W. J. M., Borsje, B. W., Wang, C., Wang, H., van der Wal, D., Zhu, Z., Oteman, B., Vuik, V., Evans, B., Möller, I., Belliard, J., Van Braeckel, A., Temmerman, S., and Bouma, T. J.: Synchronized high-resolution bed-level change and biophysical data from 10 tidal flats in northwestern Europe, [Data set], 4TU.Centre for Research Data https://doi.org/10.4121/12693254.v4, 2020.

Hu, Z., Yao, P., van der Wal, D., and Bouma, T. J.: Patterns and drivers of daily bed-level dynamics on two tidal flats with contrasting wave exposure, Sci. Rep.-UK, 7, 7088, https://doi.org/10.1038/s41598-017-07515-y, 2017.

Hunt, S., Bryan, K. R., Mullarney, J. C., and Pritchard, M.: Observations of asymmetry in contrasting wave- and tidally-dominated environments within a mesotidal basin: implications for estuarine morphological evolution, Earth Surf. Process. Landf., 41, $2207-$ 2222, https://doi.org/10.1002/esp.3985, 2016.

Knox, J. C.: Valley Alluviation in Southwestern Wisconsin, Ann. Assoc. Am. Geogr., 62, 401-410, https://doi.org/10.1111/j.14678306.1972.tb00872.x, 1972.

Le Hir, P., Roberts, W., Cazaillet, O., Christie, M., Bassoullet, P., and Bacher, C.: Characterization of intertidal flat hydrodynamics, Cont. Shelf Res., 20, 1433-1459, 2000.

Leonardi, N., Camacina, I., Donatelli, C., Ganju, N. K., Plater, A. J., Schuerch, M., and Temmerman, S.: Dynamic interactions between coastal storms and salt marshes: A review, Geomorphology, 301, 92-107, https://doi.org/10.1016/j.geomorph.2017.11.001, 2018.

Lesser, G. R., Roelvink, J. A., van Kester, J. A. T. M., and Stelling, G. S.: Development and validation of a threedimensional morphological model, Coast. Eng., 51, 883-915, https://doi.org/10.1016/j.coastaleng.2004.07.014, 2004.

Mariotti, G. and Fagherazzi, S.: A numerical model for the coupled long-term evolution of salt marshes and tidal flats, J. Geophys. Res.-Earth Surf., 115, F01004, https://doi.org/10.1029/2009JF001326, 2010.

Mcleod, E., Chmura, G. L., Bouillon, S., Salm, R., Bjork, M., Duarte, C. M., Lovelock, C. E., Schlesinger, W. H., and Silliman, B. R.: A blueprint for blue carbon: toward an improved understanding of the role of vegetated coastal habitats in sequestering $\mathrm{CO}_{2}$, Front. Ecol. Environ., 9, 552-560, https://doi.org/10.1890/110004, 2011.

Mcowen, C. J., Weatherdon, L. V., Van Bochove, J.-W., Sullivan, E., Blyth, S., Zockler, C., Stanwell-Smith, D., Kingston, N., Martin, C. S., Spalding, M., and Fletcher, S.: A global map of saltmarshes, Biodivers. Data J., 5, e11764, https://doi.org/10.3897/BDJ.5.e11764, 2017. 
Möller, I., Spencer, T., French, J. R., Leggett, D. J., and Dixon, M.: Wave transformation over salt marshes: A field and numerical modelling study from north Norfolk, England, Estuar. Coast. Shelf Sci., 49, 411-426, https://doi.org/10.1006/ecss.1999.0509, 1999.

Möller, I., Kudella, M., Rupprecht, F., Spencer, T., Paul, M., van Wesenbeeck, B. K., Wolters, G., Jensen, K., Bouma, T. J., Miranda-Lange, M., and Schimmels, S.: Wave attenuation over coastal salt marshes under storm surge conditions, Nat. Geosci., 7, 727-731, https://doi.org/10.1038/ngeo2251, 2014.

Nambu, R., Saito, H., Tanaka, Y., Higano, J., and Kuwahara, H.: Wave actions and topography determine the small-scale spatial distribution of newly settled Asari clams Ruditapes philippinarum on a tidal flat, Estuar. Coast. Shelf Sci., 99, 1-9, 2012.

Schuerch, M., Spencer, T., Temmerman, S., Kirwan, M. L., Wolff, C., Lincke, D., McOwen, C. J., Pickering, M. D., Reef, R., Vafeidis, A. T., Hinkel, J., Nicholls, R. J., and Brown, S.: Future response of global coastal wetlands to sea-level rise, Nature, 561, 231-234, https://doi.org/10.1038/s41586-018-0476-5, 2018.

Schwarz, C., Bouma, T. J., Zhang, L. Q., Temmerman, S., Ysebaert, T., and Herman, P. M. J.: Interactions between plant traits and sediment characteristics influencing species establishment and scale-dependent feedbacks in salt marsh ecosystems, Geomorphology, 250, 298-307, https://doi.org/10.1016/j.geomorph.2015.09.013, 2015.

Shi, B. W., Yang, S. L., Wang, Y. P., Yu, Q., and Li, M. L.: Intratidal erosion and deposition rates inferred from field observations of hydrodynamic and sedimentary processes: A case study of a mudflat-saltmarsh transition at the Yangtze delta front, Cont. Shelf Res., 90, 109-116, https://doi.org/10.1016/j.csr.2014.01.019, 2014.

Silinski, A., van, B., Fransen, E., Bouma, T. J., Troch, P., Meire, P., and Temmerman, S.: Quantifying critical conditions for seaward expansion of tidal marshes: A transplantation experiment, Estuar. Coast. Shelf Sci., 169, 227-237, https://doi.org/10.1016/j.ecss.2015.12.012, 2016.

Spencer, T., Möller, I., Rupprecht, F., Bouma, T. J., Wesenbeeck, B. K. van, Kudella, M., Paul, M., Jensen, K., Wolters, G., MirandaLange, M., and Schimmels, S.: Salt marsh surface survives trueto-scale simulated storm surges, Earth Surf. Process. Landf., 41, 543-552, https://doi.org/10.1002/esp.3867, 2016.

Temmerman, S. and Kirwan, M. L.: Building land with a rising sea, Science, 349, 588-589, https://doi.org/10.1126/science.aac8312, 2015.

Temmerman, S., Meire, P., Bouma, T. J., Herman, P. M. J., Ysebaert, T., and De Vriend, H. J.: Ecosystem-based coastal defence in the face of global change, Nature, 504, 79-83, https://doi.org/10.1038/nature12859, 2013.
Tucker, M. J. and Pitt, E. G.: Waves in Ocean Engineering, 1st Edn., Elsevier Science, Amsterdam, New York, 2001.

Underwood, G. J. C. and Paterson, D. M.: Recovery of intertidal benthic diatoms after biocide treatment and associated sediment dynamics, J. Mar. Biol. Assoc. UK, 73, 25, https://doi.org/10.1017/s002531540003263x, 1993.

Van Eerden, M. R., Drent, R. H., Stahl, J., and Bakker, J. P.: Connecting seas: western Palaearctic continental flyway for water birds in the perspective of changing land use and climate, Glob. Change Biol., 11, 894-908, https://doi.org/10.1111/j.13652486.2005.00940.x, 2005.

Vink, A., Steffen, H., Reinhardt, L., and Kaufmann, G.: Holocene relative sea-level change, isostatic subsidence and the radial viscosity structure of the mantle of northwest Europe (Belgium, the Netherlands, Germany, southern North Sea), Quaternary Sci. Rev., 26, 3249-3275, https://doi.org/10.1016/j.quascirev.2007.07.014, 2007.

Vuik, V., Jonkman, S. N., Borsje, B. W., and Suzuki, T.: Naturebased flood protection: The efficiency of vegetated foreshores for reducing wave loads on coastal dikes, Coast. Eng., 116, 42-56, https://doi.org/10.1016/j.coastaleng.2016.06.001, 2016.

Wang, H., van der Wal, D., Li, X., Belzen, J. V., Herman, P. M. J., Hu, Z., Ge, Z., Zhang, L., and Bouma, T. J.: Zooming in and out: scale-dependence of extrinsic and intrinsic factors affecting salt marsh erosion, J. Geophys. Res.-Earth Surf., 122, 1455-1470, https://doi.org/10.1002/2016JF004193, 2017.

Whitehouse, R. J. S. and Mitchener, H. J.: Observations of the morphodynamic behaviour of an intertidal mudflat at different timescales, Geol. Soc. Lond. Spec. Publ., 139, 255-271, https://doi.org/10.1144/GSL.SP.1998.139.01.21, 1998.

Willemsen, P. W. J. M., Borsje, B. W., Hulscher, S. J. M. H., Van der Wal, D., Zhu, Z., Oteman, B., Evans, B., Moller, I., and Bouma, T. J.: Quantifying Bed Level Change at the Transition of Tidal Flat and Salt Marsh: Can We Understand the Lateral Location of the Marsh Edge?, J. Geophys. Res.-Earth Surf., 123, 2509-2524, https://doi.org/10.1029/2018JF004742, 2018.

Yang, S. L., Li, H., Ysebaert, T., Bouma, T. J., Zhang, W. X., Wang, Y. Y., Li, P., Li, M., and Ding, P. X.: Spatial and temporal variations in sediment grain size in tidal wetlands, Yangtze Delta: On the role of physical and biotic controls, Estuar. Coast. Shelf Sci., 77, 657-671, 2008.

Zhu, Q., Yang, S., and Ma, Y.: Intra-tidal sedimentary processes associated with combined wave-current action on an exposed, erosional mudflat, southeastern Yangtze River Delta, China, Mar. Geol., 347, 95-106, https://doi.org/10.1016/j.margeo.2013.11.005, 2014. 